\title{
Law Enforcement against Children's Criminal Action Based On Law Number 11 of 2012 Concerning Children Criminal Justice Systems
}

\author{
${ }^{1}$ Feddy Hantyo Nugroho ${ }^{*}{ }^{2}$ Rodliyah, ${ }^{3}$ Amiruddin \\ ${ }^{1}$ Master of Law students, Faculty of Law, Mataram University, Indonesia \\ ${ }^{2,3}$ Lecturer Faculty of Law, Mataram University, Indonesia
}

\begin{abstract}
This research was conducted to analyze and find out how criminal law policy is in the effort to apply criminal sanctions against children facing the law in terms of Law No. 11 of 2012 concerning the Criminal Justice System for Children and whether the concept of Diversity can be applied in the process of law enforcement against children involved in Narcotics Crimes. This research is a normative study, to analyze the legal material related to the problem under study, the author uses the Interpretation, Subjective and Objective Interpretation instruments, after that the authors process these legal materials by deductive thinking. The results obtained from the study that the drafting of Law Number 11 of 2012 is a replacement to Law Number 3 of 1997 concerning juvenile justice conducted with the aim of establishing a judiciary that truly guarantees the best protection of the interests of children facing the law as nation's next generation. The concept of Restorative Justice is one of the important things in Law Number 11 of 2012 where restoring the situation as it used to be the main goal and also no less important is the form of criminal sanctions that can be imposed on Children where criminal sanctions that are harsh and miserable are used as ultimum Remedium is not as a premium remedium especially as a maximum remedium. The concept of diversion that should be applied in Indonesia in the future, should be a combination of the concept of diversion that is applied in Australia, namely Police Diversion which is combined with the process of handling cases with the diversion prevailing in Indonesia today.
\end{abstract}

Keywords: Law Enforcement, Children of Perpetrators, Narcotics

\section{Introduction}

That related to Law Enforcement actions in the context of eradicating Narcotics criminal acts, is always guided by Law Number 35 of 2009 concerning Narcotics, including criminal threats that must be applied to Narcotics offenders. That the criminal threat applied to the perpetrators of criminal acts in the current era is not only the threat of imprisonment but will also be followed by the threat of fines and minimal penalties. It aims to provide a deterrent effect for the perpetrators as well as provide an overview to the wider community so as not to commit the crime.

Theoretically and legally the use of criminal sanctions for children is still possible, even though very stringent requirements are determined. That is, the downfall must be very selective and its implementation must be adapted to the child's psychological condition. The use of criminal sanctions for children cannot be equated with the use of criminal sanctions for adults. Whereas based on Article 81 Paragraph (2) of Law Number 11 Year 2012 concerning the Juvenile Justice System it is stated that Criminal imprisonment can be imposed on a child no later than $1 / 2$ (one-half) of the maximum threat of imprisonment for adults. If a child is suspected of having committed a Narcotics Act in accordance with article 114 paragraph (1) of Law Number 35 of 2009 concerning Narcotics with a minimum of 5 (five) years and a maximum of 20 (twenty) years, then the child will receive a criminal threat $1 / 2$ of 20 (twenty) years, i.e. 10 (ten) years and without minimal threats because based on article 79 paragraph (3) of Law Number 11 of 2012 against Children, there is no specific minimum threat of imprisonment. That although the threat of imprisonment against children is $1 / 2$ (one half) of an adult, if you see the example above, the criminal threat can still be said to be very high for a child. 
The use of criminal law as a means of overcoming narcotics abuse by children is essentially a dilemma choice. On the one hand, the ability of criminal law as a means of dealing with narcotics abuse by children is very limited. Indications of this can be seen among others from the increasing abuse of narcotics committed by children, while on the other hand there is a tendency to always use criminal law as a means of overcoming narcotics abuse committed by children. Whereas reality shows that criminal justice as a means of overcoming narcotics abuse by children often presents itself only as "procedural justice". So the results are often unsatisfactory and clearly ignore the interests and welfare of children.

While actions to prevent the distribution of narcotics among young people and school-age children include the inclusion of education related to the consequences of drug abuse in the elementary to high school curriculum, in addition to these measures, efforts to rescue and eradicate children from the involvement of narcotics abuse that results in destruction and disgrace is a strategic step that can be taken by the Government. This assertion implies, that children must get protection for their rights under any circumstances. Furthermore, in Article 1 point 15 of Law Number 23 of 2002 concerning Protection of Children, it is stipulated that Special Protection is protection given to children in emergency situations, children who are dealing with the law, children from minority and isolated groups, children who are economically exploited and/or sexual, trafficked children, children who are victims of narcotics, alcohol abuse and other addictive substances.

That the protection of children in conflict with the law also received international attention, beginning with the existence of the Geneva Declaration on "Children's Rights in 1924" which was later confirmed in United Nations Resolution No. 1386 (XIV, November 20, 1959) concerning the "Declaration of The Right of Child". Finally there is the convention of children's rights (Convention on the Right of the Child 1989) which is then set forth in United Nations Resolution No. 44/25 / December 5, 1989. This Convention has been ratified by Presidential Decree Number 36 of 1990, which among others states that: and special care including proper legal protection, before and after his birth ". That the aforementioned thought construction is the reason for the writer to dig deeper related to the model of law enforcement that is appropriately applied to Children Facing Laws in Narcotics cases.

\section{Results and Discussion}

\section{Special Dimensions of Justice Against Children Who Are Confronting the Law}

The principle of legal protection for children must be in accordance with the Convention on the Rights of the Child as ratified by the Government of the Republic of Indonesia with Presidential Decree Number 36 of 1990 concerning Ratification of the Convention on the Rights of the Child.

Law No. 3/1997 on juvenile justice is intended to protect and nurture children who are in conflict with the law so that children can meet their long future and provide opportunities for children so that through coaching will obtain their identity to become independent, responsible and useful children for oneself, family, community, nation and country. However, in its implementation the child is positioned as an object and the treatment of children in conflict with the law tends to harm the child. In addition, the law is no longer in accordance with the legal needs in the community and has not yet comprehensively provided special protection for children in conflict with the law.

Thus, there needs to be a paradigm shift in the handling of Children in Confronting the Law, among others based on the roles and duties of the community, government and other state institutions that are obliged and responsible to improve the welfare of children and provide special protection for Children who are in conflict with the Law. The drafting of Law Number 11 of 2012 is a replacement to Law Number 3 of 1997 concerning Juvenile Justice (State Gazette of the Republic of Indonesia Number 3 of 1997, Supplement to the State Gazette of the Republic of Indonesia Number 3368) which is carried out with the aim of establishing a true trial truly guarantee the protection of the best interests of the child who is dealing with the law as the successor to the nation ${ }^{1}$.

${ }^{1}$ Explanation of Law Number 11 Year 2012 concerning SPPA, Director General of Human Rights at the Ministry of Law and Human Rights of the Republic of Indonesia 
Law Number 11 of 2012 using the name of the Juvenile Criminal System is not interpreted as a judicial body as regulated in article 24 paragraph (2) of the 1945 Constitution of the Republic of Indonesia which states that the powers of the Judiciary are exercised by the Supreme Court and the judiciary located below that in the general court environment, the religious court environment, the military court environment, the State Administrative court environment and by the Constitutional Court. The substance regulated in Law Number 11 of 2012 includes the placement of children undergoing judicial proceedings which can be placed in a Special Child Development Institute. The most basic substance in Law Number 11 of 2012 is the strict regulation of Restorative Justice and Diversity which is intended to avoid and keep children away from the judicial process so as to avoid stigmatization of children in conflict with the law and it is hoped that children can return to the social environment as a whole. reasonable.

The concept of Restorative Justice towards Child offenders is certainly in line with the fundamental changes from the Narcotics Act number 22 of 1997 to the Narcotics Act Number 35 of 2009 where the State's perspective on narcotics users is no longer a criminal but sees it as a victim limitatively it has been regulated in the explanation of article 54 of Narcotics Law Number 35 of 2009 stated that the victim of narcotics abuse is someone who accidentally used narcotics because he was persuaded, tricked, deceived, forced and / or threatened to use narcotics.

In accordance with the principle of Dominus Litis, the determination and control of the prosecution policy is only one hand so that the role of the Public Prosecutor in proof is very important and is the responsibility of the Prosecutor as the Public Prosecutor. For the Public Prosecutor, proof is a very determinant factor in order to support his duty as a party that has a burden to prove the accused's guilt. If a child offender is suspected of committing drug abuse, the Narcotics Act No. 35 of 2009 formulates the risk of criminal threats as stipulated in article 127 where the responsibility lies with the child offender, who is also the victim. Proving that the abuser is a victim is not easy for the Public Prosecutor because he must see the beginning of narcotics users using narcotics and proof that narcotics use is persuaded, tricked, tricked, used and / or threatened with narcotics.

Proof that the child perpetrators are victims of narcotics based on the principle of proof that applies in the Child Criminal Justice System in addition there are provisions that must be met, namely²:

1. When arrested in the condition of being caught red-handed;

2. When caught red-handed, one-time evidence was found with details including: 1 gram of Metamphetamine, MDMA (ecstasy) 2.4 grams / 8 items, 1.8 grams of Heroin, 1.8 grams of Cocaine, 5 grams of Marijuana, etc. ;

3. Positive Laboratory Test Certificate (+) using narcotics based on the request of the investigator;

4. Not a recidivist drug or psychotropic criminal case

5. There is an Assessment from a Doctor recorded in the medical record, the need for medical and social rehabilitation based on the Supreme Court Circular Letter Number 4 of 2010;

6. There is no evidence that the child offenders are concurrently becoming narcotics dealers / illicit producers;

7. The duration of rehabilitation by taking into account the conditions of addiction to the child offender based on expert statements.

Those requirements become one of the concepts of Restorative Justice that can be applied to child offenders who commit narcotics abuse by sticking to Article 71 of Law Number 11 Year 2012 concerning the Juvenile Justice System which regulates the form of criminal sanctions that can be imposed on Children where criminal sanctions that are hard and miserable must be used as an ultimum remedium not as a premium remedium let alone as a maximum remedium.

\section{Diversion in the Perspective of the Development of the Criminal Law of Children}

There is a view that the use of criminal law as a means of combating crime cannot be ordained with the understanding that its use must still be of a subsidiary nature. That is, as long as the use of facilities outside

${ }^{2}$ General Attorney General Circular Letter Number: B-136 / E / EJP / 01/2012 dated January 12, 2012 concerning the demands for medical rehabilitation and social rehabilitation based on Government Regulation of the Republic of Indonesia Number 25 of 2011 concerning the Implementation of Narcotics Addicts Obligatory Reporting 
the criminal justice system as a whole, then the humanistic approach must also be considered. This is important not only because the crime is essentially a human problem ${ }^{3}$, but also because in essence the criminal law itself contains an element of suffering that can attack the most valuable interests or values for human life. Therefore the use of criminal law as a means of combating crime cannot be ordained, even its use must be integrated with instruments / facilities outside the criminal justice system.

Conceptually, crime prevention can be done either by using criminal justice (judicial) or other means outside of criminal justice (non-judicial). Efforts to divert the process from the judicial process to the non-judicial process in overcoming narcotics abuse by children, basically an effort to resolve narcotics abuse committed by children outside the criminal justice path. This means that the transfer of the process from the judicial process to the non-judicial process in dealing with narcotics abuse by children is basically an effort to prevent children from applying criminal law and criminal punishment.

Diversity in essence also has the goal of avoiding children and the negative impact of criminal application. Diversion also has the essence of ensuring that children grow and develop both physically and mentally. Theoretically reviewed from the concept of criminal purpose, the transfer of the process and the judicial process to the non-judicial process of children who commit drug abuse will look relevant as follows:

1. In general, the objective of punishment consists essentially and efforts to protect the community on the one hand and protect individuals (perpetrators) on the other ${ }^{4}$. The relevance of the transfer of the process and the judicial process to the non-judicial process in overcoming child abuse of narcotics against the two main aspects of the goal of criminal punishment, namely aspects of community protection and aspects of individual protection can be explained as follows:

a. With this transfer, the child will be spared and the application of criminal law which in many theories has been postulated as a factor of criminogen. The negative impact of the application of criminal law, including to children, will give birth to stigmatization and dehumanization which can actually be criminogenic factors. Thus, avoiding children and the application of criminal law (depenalization) can in fact avoid the existence of criminogenic factors, which means also avoiding children and the possibility of becoming evil again (recidivist), therefore also means avoiding the community and possibly becoming victims of crime.

b. Diversion / transfer will also provide two benefits at once to individual children. First, with this transfer the child will still be able to communicate with the environment, so that the child will no longer need to make social adaptations after the crime. Secondly, by this transfer the child will avoid the negative impact of prison which is often a means of "transferring" crime.

In its development, criminal law also needs to pay attention to victims of crime. The orientation of criminal law which only tends to the problem of acts (criminal) and perpetrators (daad-dader strafrecht) has given rise to the construction of criminal law that does not respect victims. Whereas in context, children as people who abuse narcotics cannot be seen merely as perpetrators, but they must also be seen as victims who need priority in alleviating their dependence on narcotics.

The transfer of the process from the judicial process to the non-judicial process is also very relevant to the philosophy of punishment adopted in general, namely the philosophy of guidance (philosopy treatment). Thus, the transfer of the process from the judicial to the non-judicial process also has relevance to the conceptual transformation in the criminal and criminal system that occurs in the world in general and the conception of retribution towards the conception of reform ${ }^{5}$.

To discuss the legal position of diversion against children who abuse narcotics from a criminal law perspective, it is necessary to discuss the development of diversion policy.

\footnotetext{
${ }^{3}$ Barda Nawawil Arief, Kebijakan Legislatif dalam Penanggulangan Kejahatan dengan Pidana Penjara, Badan Penerb it Universitas Diponegoro, Semarang, 1994, hlm. 41.

${ }_{5}^{4}$ Barda Nawawi Arief, Op.Cit.,.

${ }^{5}$ Jimly Asshiddiqie, Pembaharuan Hukum Pidana Indonesia Studi tentang Bentuk-Bentuk Pidana Dalam Tradisi Fiqh dan Relevansinya Bagi Usaha Pembaharuan KUHP Nasional, Penerbit Angkasa, Bandung, 1996, hlm. 167.
} 


\section{Diversity in International Legal Instruments}

The mandate to prevent children from applying crime is called on by the international community in various international legal instruments relating to the application of crime for children. can be mentioned, among others, The United Nations Guidelines for the Prevention of Juvenile Delinquency (The Riyadh Guidelines). One of the international instruments relating to the application of crime for children is the United Nations Guidelines for the Prevention of Juvenile Delinquency listed in UN Resolution 45/112 of December 14, 1990. Some important matters contained in UN Resolution $45 / 112$ are related to criminal application for children ${ }^{6}$.

The United Nations for the Administration of Juvenile Justice (The Beijing Rules) was adopted on September 6, 1985 and was adopted as the UN Resolution on November 29, 1985 in Resolution 40/33. ${ }^{7}$

The United Nations Rules for the Protection of Juvenile Deprived of Liberty This international instrument is contained in United Nations Resolution 45/113 which came into force on 14 December 1990. Substantially the United Nations Rules for the Protection of Juvenile Deprived of Liberty contains a establishment of Minimum Standards for the protection of children deprived of their independence, as well as a reference for law enforcement officials dealing with juvenile justice. ${ }^{8}$ Various provisions contained in The United Nations Rules for the Protection of Juvenile Deprived of Liberty can be concluded that although deprivation of liberty of children (perpetrators of crime) is possible, but the basic prerequisites for depriving children of liberty are so strict. This means that deprivation of liberty against children should not be carried out only on the grounds that the child concerned has committed a crime. Deprivation of liberty of children according to the United Nations Rules for the Protection of Juvenile Deprived of Liberty carries consequences in such a way that children must still have respect for their human rights.

Based on the provisions contained in the above international instruments, the policy to avoid children and the judicial process must be carried out comprehensively. Partial handling of children will actually put the child in conditions that are unfavorable for the child's coaching process. Through comprehensive social policies children are directed to grow healthily both physically and mentally. This effort is essentially an attempt to keep children away and possibly be involved in the judicial process by means of non-penal incentives.

In the social context it has become a common view, that relating to the police is an indication, that the person concerned is a bad person. Thus, it is understandable if this international instrument also suggests that it is necessary to prioritize the transfer of handling and the judicial process to the non-judicial process (diversion). The implementation of the diversion process as an attempt to shift from the judicial process to the non-judicial process is a response to the reality that ill treatment and negative impacts in the criminal justice process.

\section{Diversity of Narcotics Abuse Children in the Indonesian Criminal Justice System}

Basically, criminal law policies in dealing with drugs in Indonesia have long been done. Beginning with the entry into force of the Drug Ordinance (Verdoovende Middelen Ordonnantie, Stbl. 1927No.278jo. No.536). This ordinance was later replaced by Law No. 9 of 1976 concerning Narcotics. Furthermore, this law was changed to Law No. 22 of 1997 concerning Narcotics until the advent of Law no. 35 of 2009 as the latest update of the law on Narcotics.

The use of criminal law as a means of tackling narcotics abuse by children is essentially a dilemma choice. Given the criminal justice as a means of overcoming narcotics abuse by children often presents itself only as a "machine" of the law that will only produce "procedural justice" (procedural justice). So the results are often unsatisfactory and clearly ignore the interests and welfare of children. So the results are often unsatisfactory and clearly ignore the interests and welfare of children.

Starting from the thought that the potential for a negative impact on children due to criminal justice processes is very large. The negative impact of criminal justice processes such as prisonization,

\footnotetext{
${ }^{6}$ Paulus Hadisoeprapto, Juvenile Delinquency(Pemahaman dan penaggulangannya), Citra Aditya Bakti, Bandung, 1997, hlm. 101 .

${ }^{7}$ Ibid.,hlm. 109.

${ }^{8}$ Ibid.hlm. 123.
} 
dehumanization and stigmatization will disrupt the growth of children's lives. In this context, the effort to shift the handling of children from the judicial path to the non-judicial path (diversion) becomes very urgent.

Through diversion to the behavior of children who deviate or commit crimes, a better solution can be done, without ignoring the interests and welfare of children, and can take appropriate action in accordance with the needs and interests of children. This diversion or diversion policy is the best solution that can be used as a formula in the settlement of several cases involving children as perpetrators of crime, especially in the handling of children who abuse narcotics. So it will be more appropriate in determining the actions (treatment) that need to be applied to it. As confirmed by Larry J. Siegel, who stated as follows :

"Most diversion programs are carried out by using a special formula to select teenagers who are included in the diversion program. Criteria such as a new offender, non-violent offender, or an offender, or alcoholic drink addict are used to select clients. In certain programs, the teenager will be asked to voluntarily participate in community service instead of attending court. In other programs, prosecutors will agree to reject and close a case after an adolescent completes a treatment program. Finally, some programs can be implemented by juvenile judges after the initial hearing) "

Diversion is a non-penal policy measure for dealing with child offenders, because its handling is diverted outside the path of the juvenile justice system, through short-term coaching or other coaching methods. Diversi departs from the assumption that the process of handling children through the juvenile justice system is more likely to be negative than positive for children's development.

Related to the handling of narcotics abuser children, the main problem arising from the juvenile criminal justice process or a criminal verdict is the Stigma attached to convicted of narcotics abuse after the completion of the criminal justice process. The tendency of increasing narcotics abuse by children or young offenders, encourages efforts to deal with and deal specifically with it in the field of criminal law both formally and materially. In the perspective of criminal policy, crime prevention is essentially a rational effort and the community in tackling crime ${ }^{10}$. As a rational and community effort, crime prevention, including narcotics abuse prevention, must be based on proper diagnosis and diagnosis.

Basically a child who abuses narcotics cannot be seen merely as a criminal, but must also be seen as a victim. This paradigmatic approach essentially departs and the thought that (crime) narcotics abuse can qualify as a crime whithout victim. Thus, victims of narcotics abuse crimes are the perpetrators themselves, not others. Therefore, it is not appropriate if in the case of narcotics abuse, the person concerned is only seen as a perpetrator and not as a victim. Affirmation of this issue is seen as very urgent regarding the efforts that must be taken in its response.

It should be underlined, that the treatment of perpetrators of criminal acts with the treatment of victims is not the same. Thus, understanding the position of a child involved in a crime is a measure to see the extent of the accuracy of the treatment given to him. In other words, the affirmation of this issue is important to determine the drugs that must be given. Does he have to be convicted, because he is only seen as a perpetrator or rather he must get rehabilitation because he is seen as a victim. With the accuracy of the diagnosis, the drugs that must be given to him will also be appropriate and effective.

Starting from this thought, the handling of narcotics abuse by children using criminal law is deemed inappropriate. This view departs from several reasons as follows: First, as a means of overcoming crime, criminal law is basically a drug that is only oriented towards prevention after the occurrence of crime. Thus, the use of criminal law as a means of overcoming crime is only corrective and repressive in nature. Such an approach can be tolerated when it is only oriented towards the perpetrators of criminal acts. In fact, children who commit narcotics misuse are not only as perpetrators of crime, but also as victims. Second, starting from the thought, that children who abuse narcotics are also victims, then efforts to provide protection for children who abuse narcotics are also a priority.

The handling of narcotics-abused children can be used as an alternative punishment method with the restorative principle. This principle positions the criminal process against children as "The Last Resort" not

\footnotetext{
${ }^{9}$ Ibid, hlm. 322-323.

${ }^{10}$ Sudarto, Hukum dan Hukum Pidana, Alumni, Bandung, 1982, hlm. 38.
} 
"The First Resort". In criminal law theory it is also called Ultimum Remedium. It is intended that children can improve themselves in accordance with the wishes and interests of the child (The Best Interest of the Child) when he is dealing with the law. Although punishment is a powerful tool owned by the State to combat crime, it is not the only means to improve the situation, there must be a combination of repressive and preventive efforts in handling narcotics abusers, through diversion through medical rehabilitation and social rehabilitation.

Regarding the handling of children as narcotics abusers, in addition to being carried out by the Public Prosecutor at the Prosecution stage based on data from the National Narcotics Agency of West Nusa Tenggara Province, medical rehabilitation has also been carried out both on Children reporting voluntarily to obtain medical rehabilitation or on Children undergoing medical rehabilitation at the investigation stage, which is as follows:

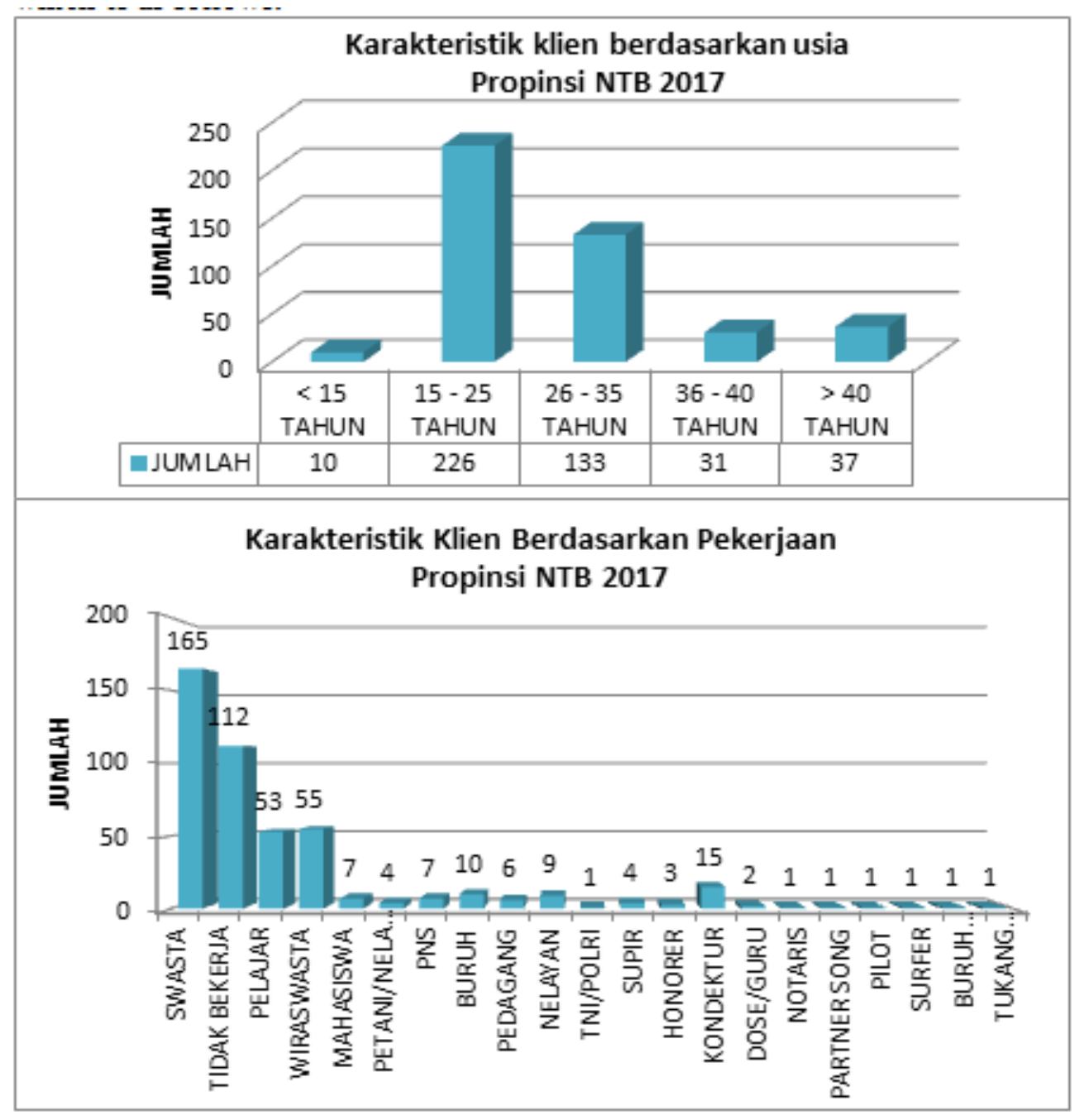

West Nusa Tenggara Province Narcotics National Agency 2017

Observing data from the National Narcotics Agency of the West Nusa Tenggara Province, it is seen that the number of abusers aged 15-25 years and the status of students is quite a lot, so that strategic steps are needed to tackle narcotics abuse among adolescents / children, bearing in mind in addition to the peculiar conditions of mental and mental development conditions, adolescents/Children are the next generation who must receive protection for the sake of their conducive development, in this case medical rehabilitation efforts and social rehabilitation carried out on adolescents/Children are strategic steps and good in efforts to restore the conditions and conditions of adolescents/Children as they were before adolescents / children involved in narcotics abuse ${ }^{11}$. 


\section{The Diversi Concept of Handling Narcotics Abuse Children in the Indonesian Child Criminal Justice System for the Future}

The philosophy of the juvenile justice system is to prioritize protection and rehabilitation of child offenders (emphasized the rehabilitation of youthful offender) as people who still have a number of limitations compared to adults. Children need protection from the state and society in the long term ahead ${ }^{12}$. For a child who is already a criminal, a criminal justice system strategy is needed, which is to try to minimize the intervention of the criminal justice system ${ }^{13}$.

Children who break the law or commit crimes are greatly influenced by several other factors outside the child such as association, education, playmates and so on. To protect children from the influence of the formal process of the criminal justice system, human or legal and humanitarian thought arises to make formal rules of action to remove a child who violates the law or commits a crime from the criminal justice process by providing other alternatives which is considered better for children. Based on these thoughts, the concept of diversion was born, which in Indonesian terms is called diversion.

According to Jack E. Bynum in his book Juvenile Delinquency a Sociological Application, which is: "Diversion is an attempt to divert, or channel out, youthful offenders from the juvenile justice system" out of the criminal justice system. ${ }^{14}$

The concept of diversion is based on the fact that the criminal justice process against children who commit crimes through the criminal justice system poses more harm than good. The basic reason is that the court will stigmatize the child for the actions he committed like a child is considered evil, so it is better to avoid it outside the criminal justice system ${ }^{15}$.

Based on the United Nations Standard Minimum Rules for the Administration of Juvenile Justice or the socalled The Beijing Rules (Office of the High Commissioner for Human Rights, 1985) points 6 and 11 contain statements regarding diversion which is the process of delegating children in conflict with the law from criminal justice system to informal processes such as returning to social institutions, both government and non-government.

Considerations were made by the court to diversify the philosophy of the juvenile justice system to protect and rehabilitate children of offenders. The diversion was also carried out as an effort to prevent a child offender from becoming an adult criminal. It is this child prevention effort that brings law enforcement officials to take discretionary authority or in the United States is often referred to as deinstitutionalisation of the formal criminal justice system.

The main principle of implementing the diversion concept is persuasive action or non-penal approach that gives an opportunity for someone to correct mistakes. One background to the importance of diversion policies in handling children in conflict with the law is due to the high number of children entering criminal justice and being sentenced to prison and experiencing violence while undergoing a series of processes in the criminal justice system.

Diversion is done with the reason to provide an opportunity for lawbreakers to become good people again through non-formal channels by involving community resources. Diversi seeks to provide justice for children in conflict with the law. Both justice is explained through a writing of circumstances and situations to obtain sanctions or appropriatetreatment ${ }^{16}$.

\footnotetext{
${ }^{12}$ Nicholas M.C. Bala dan Rebecca Jaremko Bromwich Chapter 1, Introduction: An International Perspective On Youth Justice dalam buku Nicholas M.C. Bala, et al..Juvenile Justice System an International Comparison of Problem and Solutions, Eduacational Publishing Inc, Toronto,2002,hlm. 5.

${ }^{13}$ Kevin Haines dan Mark Drakeford, Young People and Youth Justice, Macmillan Press Ltd, Houndmills Basingstoke Hampshire RG21 6XS and London,1998,hlm. 73.

${ }^{14}$ Jack E Bynumn \& William E. Thompson,Juvenile Delinquency a Sociological Approach., Allyn and Bacon A Peason Education Company, Boston,2002, hlm. 430.

${ }^{15}$ Randall G. Shelden, Detention Diversion Advocacy: An Evaluation, Department of Justice, Washington DC U.S. 1997, hlm. 1 .

${ }^{16}$ Walker, Training The System The Control of Discretion in Criminal Justice 1950-1990, Oxford University Press, New York, 1993, hlm. 1-2.
} 
With the application of the diversion concept, the handling of children in conflict with the law is oriented to provide protection for children from imprisonment. In addition, it can be seen that protecting children with diversion policies can be carried out at all levels of the judiciary starting from the community before the occurrence of criminal acts by taking precautions. After that, if a child has committed an offense, it does not need to be processed into the criminal justice process.

Furthermore, if a child who has committed an offense has already been arrested by the police, the police can conduct diversion without proceeding to the Public Prosecutor. Then if the child case has reached the prosecution process by the Public Prosecutor then the Public Prosecutor has the obligation to carry out the diversion process in the court, then the judge can conduct judicial proceedings in accordance with the procedure and preferably the child can be released from imprisonment. Finally, if the child is already in prison, prison officials can make a diversion policy against children so that children can be delegated to social institutions, or alternative sanctions that are useful for the development and future of children ${ }^{17}$.

In Indonesia, the concept of diversion towards children as one component of the improvement of the structure of the juvenile justice system as an alternative to formal criminal justice, by putting diversion efforts at each stage of the judicial process. This is different from Australia, where applying the concept of diversion to children is not an alternative program, but a diversion to exclude from the justice system. This form of diversion in Australia began to be carried out in the state of Victoria in 1959, Queensland in 1963 and New South Wales in 1985 all in the Australian State.

States such as Victoria, New South Wales and Queensland have dared to reform their existing legal systems to support the implementation of the diversion program perfectly. Wundersitz called the implementation of diversion in these countries with the term "principle of the frugality of punishment". ${ }^{18}$

The concept of diversion that should be applied in Indonesia in the future, is not much different from the concept of diversion that is applied in Australia, namely Police Diversion and combined with the diversion system that has been implemented in Indonesia at this time. This is based on the consideration of the Police as the first gate to deal with children in conflict with the law to determine whether a child will proceed to the judicial process or other informal actions.

In addition to trying to override the judicial process in the settlement of cases of narcotics-abused children, children also have the right to be recovered from the physical and psychological recovery of the child as before, where the child is also treated as a result of drug abuse and addictive substances in a medical rehabilitation institution to recover "illness "He suffered so that the child becomes clean from the consequences of drug abuse.

If the diversion is not successful at the investigation stage in the Police, the diversion will continue to be pursued at the prosecution level by the Public Prosecutor and if it is not succeeded at the diversion at the prosecution level, the final attempt will be carried out at the trial, so that the diversion of the child offender is maximally sought at each stage of handling cases so that the Child is still protected by his rights and still has the opportunity for diversion.

\section{Conclusion}

The drafting of Law Number 11 of 2012 is a replacement to Law Number 3 of 1997 concerning Juvenile Justice conducted with the aim of establishing a judiciary that truly guarantees the best interests of protection of Children in Confront with the Law as the nation's successors. The concept of Restorative Justice is one of the important things in Law Number 11 of 2012 where restoring the situation as it used to be the main goal and also no less important is the form of criminal sanctions that can be imposed on Children where criminal sanctions that are harsh and miserable are used as ultimum Remedium is not as a premium remedium especially as a maximum remedium.

17 Kenneht Folk, Early Intervention: Diversion and Youth Conferencing, A national review of current approach to diverting juvenile from the criminal justice system, Commonwealth of Australia Government Attorney-general's Departement Australia, Canberra, 2003,hlm. 4.

${ }^{18}$ Ibid,hlm. 6. 
The concept of diversion that should be applied in Indonesia in the future, should be a combination of the concept of diversion that is applied in Australia, namely Police Diversion which is combined with the process of handling cases with the diversion prevailing in Indonesia today. This is based on the consideration of the Police as the first gate to deal with children in conflict with the law to determine whether a child will proceed to the judicial process or other informal actions with the supervision of the Public Prosecutor as Dominus Litis/the prosecution controller. Diversification must be carried out at the stage of investigation, prosecution and trial with the best interests of the child. When the diversion attempt fails to reach an agreement in all three stages, the settlement of the case of the child is carried out in a Penal manner but does not rule out the right to recover from returning to the physical and psychological condition of the Child as before, where the child is also treated for drug abuse due to narcotics and addictive substances in a medical rehabilitation institution to recover the "illness" he suffered so that the child becomes clean from the consequences of narcotics abuse.

\section{Reference}

[1.] Explanation of Republic of Indonesia Law Number 11 Year 2012 concerning the Juvenile Criminal System, Director General of Human Rights at the Ministry of Law and Human Rights of the Republic of Indonesia

[2.] General Attorney General Circular Letter Number: B-136 / E / EJP / 01/2012 dated January 12, 2012 concerning the demands for medical rehabilitation and social rehabilitation based on Government Regulation of the Republic of Indonesia Number 25 of 2011 concerning the Implementation of Narcotics Addicts Obligatory Reporting

[3.] Barda Nawawil Arief, Kebijakan Legislatif dalam Penanggulangan Kejahatan dengan Pidana Penjara, Badan Penerb it Universitas Diponegoro, Semarang, 1994.

[4.] Jimly Asshiddiqie, Pembaharuan Hukum Pidana Indonesia Studi tentang Bentuk-Bentuk Pidana Dalam Tradisi Fiqh dan Relevansinya Bagi Usaha Pembaharuan KUHP Nasional, Penerbit Angkasa, Bandung, 1996.

[5.] Paulus Hadisoeprapto, Juvenile Delinquency(Pemahaman dan penaggulangannya), Citra Aditya Bakti, Bandung, 1997.

[6.] Sudarto, Hukum dan Hukum Pidana, Alumni, Bandung, 1982.

[7.] Nicholas M.C. Bala dan Rebecca Jaremko Bromwich Chapter 1, Introduction: An International Perspective On Youth Justice dalam buku Nicholas M.C. Bala, et al..Juvenile Justice System an International Comparison of Problem and Solutions, Eduacational Publishing Inc, Toronto,2002.

[8.] Kevin Haines dan Mark Drakeford, Young People and Youth Justice, Macmillan Press Ltd, Houndmills Basingstoke Hampshire RG21 6XS and London,1998.

[9.] Jack E Bynumn \& William E. Thompson,Juvenile Delinquency a Sociological Approach., Allyn and Bacon A Peason Education Company, Boston,2002.

[10.] Randall G. Shelden, Detention Diversion Advocacy: An Evaluation,Department of Justice, Washington DC U.S. 1997.

[11.] Walker, Training The System The Control of Discretion in Criminal Justice 1950-1990, Oxford University Press, New York, 1993.

[12.] Kenneht Folk, Early Intervention: Diversion and Youth Conferencing, A national review of current approach to diverting juvenile from the criminal justice system, Commonwealth of Australia Government Attorney-general's Departement Australia, Canberra, 2003.

[13.] Law Number 3 of 1997 concerning Juvenile Justice

[14.] Law Number 11 Year 2012 concerning the Juvenile Criminal System 